\title{
UPLIFT CAPACITY OF SINGLE AND GROUP OF GRANULAR ANCHOR PILE SYSTEM
}

\author{
Pradeep Kumar ${ }^{1}$, Mohit Kumar², V. K. Chandaluri ${ }^{3}$ and V. A. Sawant ${ }^{4}$ \\ ${ }^{1}$ Central Building Research Institute Roorkee, Roorkee 247667, India \\ 2,3,4 Department of Civil Engineering, Indian Institute of Technology Roorkee, Roorkee 247667, India
}

Date received: 28/02/2018, Date accepted: 19/04/2018

Corresponding author's email: sawntfce@iitr.ac.in

\begin{abstract}
In view of increased development in the infrastructure across the world, now it becomes necessary to go for the marginal sites having weak soil for foundation. Foundations are normally designed to transfer compressive and uplift forces safely to the subsoil, wherein piles provide an appropriate solution. But the option of pile foundation is quite expensive. Before going for pile foundation, the feasibility of other alternatives must be accessed thoroughly. If it is possible to adopt some suitable ground improvement technique for enhancement of foundation strength, then it should be considered. In the present study, Granular Anchor Pile System is proposed to with stand uplift forces. The present paper, based on a field study, briefly discusses the basic principles associated with the granular pile. The analysis of field test data indicates that the proposed granular pile system is a viable means for ground improvement. It is found effective for improving varying soil conditions and capable of providing resistance to compressive forces in addition to the uplift resistance. Besides, this foundation technique has been found cost effective as compared to the concrete piles.
\end{abstract}

Copyright $\odot 2018$ UNIMAS Publisher. This is an open access article distributed under the Creative Commons Attribution-NonCommercial-ShareAlike 4.0 International License which permits unrestricted use, distribution, and reproduction in any medium, provided the original work is properly cited.

Keywords: Granular anchor pile, uplift capacity, anchor plate

\subsection{INTRODUCTION}

Keeping in view the emerging demand of infrastructure, utilization of the poor and marginal sites is unavoidable. Development of these sites with ground improvement techniques has become a subject of profound interest for geotechnical engineers. A variety of ground improvement methods are in practice these days. Various compaction techniques can be adopted for stabilization of loose cohesionless soils. For cohesive soils, consolidation by preloading, grouting, electro-osmosis, electrochemical hardening, stabilization through lime columns, are preferred ground improvement techniques. Ground improvement by various methods can be quantified by assessing the improved bearing capacity and reduced settlement of the treated ground. In real field situations one may come across situations like, limited area for foundation due to presence of existing structures, or where piling may not be adopted due risks of settlement from vibrations, excavations/ loss of ground. In such situations, granular piles can be used as an economical and effective alternative. Installing granular piles in soft cohesive soils and loose cohesionless deposits is an accepted and popular ground improvement technique [1]. Granular pile installation does not require heavy machinery or skilled labour like pile foundation. Gravel backfill is placed into the borehole in stages. In each stage, backfill is compacted by a steel hammer. Compaction displaces the filling material in radial outward direction resulting densification of surrounding soil. This has resulted in significant increase in load carrying capacity and reduction in settlement. Installation of granular piles is one of most preferred method of improving soft ground or loose sand deposits. Granular piles act as reinforcement in the subsoil. It improves drainage pattern and helps in dissipation of excess pore water pressure. Installation of granular pile results in densification of surrounding soil. This will improve bearing capacity, the rate of consolidation and the liquefaction resistance of the ground. In addition, total and differential settlements get reduced by $60-80 \%$. In field, granular piles are installed with the help of vibro-processes or through rammed stone columns technique. 
Structures like transmission towers or foundations on expansive soil are subjected to uplift forces. In such case, conventional approach is to adopt under-reamed pile foundation. But in the present study, normal granular pile technique with little modification is suggested to counter the uplift force. 'Granular Anchor Pile (GAP)' is the modified form of granular pile. It may be defined as the enhanced granular pile which is reinforced with anchor plate and anchor rod. An anchor plate is a circular steel plate embedded into a concrete pedestal at the bottom of predrilled hole. It is connected to a steel anchor rod which may protrude above pile head (Figure 1).

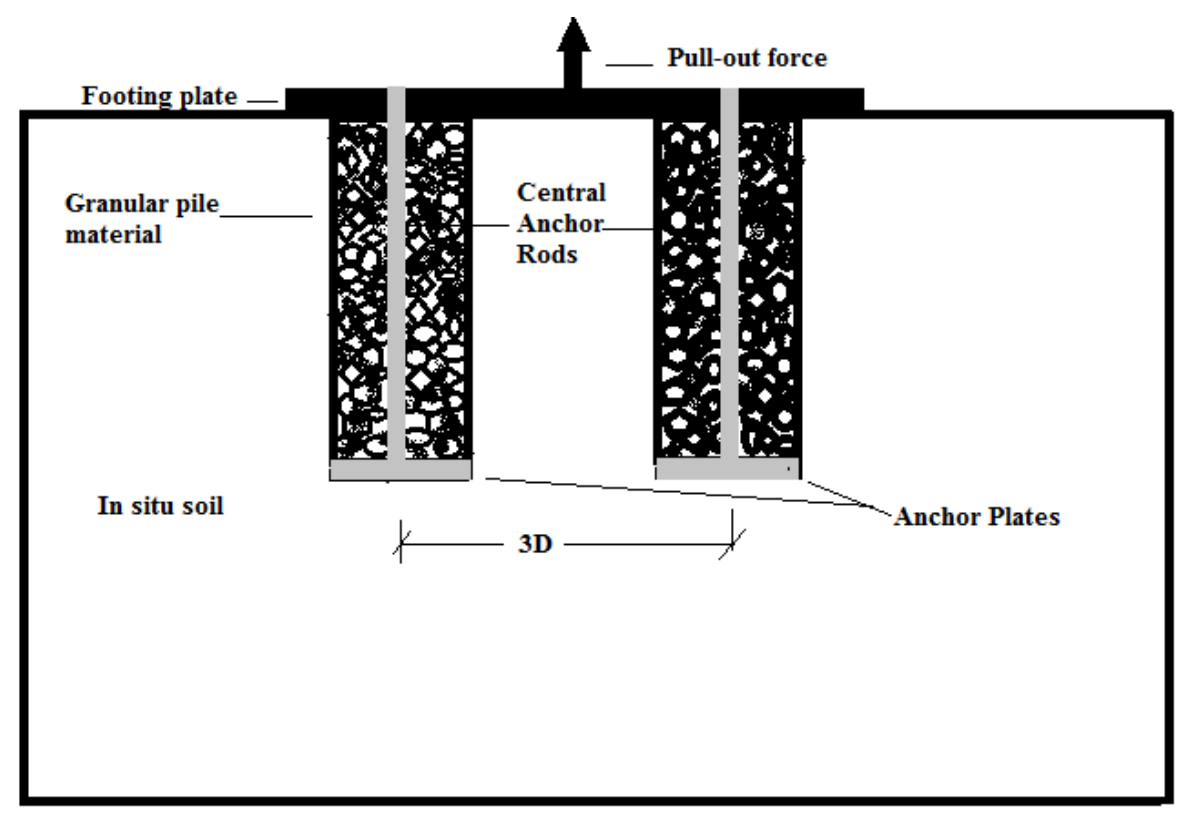

Figure 1 Concept of the granular anchor pile (GAP) foundation system

Few studies have been reported on granular anchored pile to resist uplift forces [1-5]. Kumar and Ranjan [6] have reported the field study of GAP system. Phanikumar et al. [7] reported laboratory investigations on a limited scale for heave control of expansive soils. Ibrahim et al. [8] conducted laboratory tests in addition to a series of numerical modelling using PLAXIS software to study the behavior of GAPF system in expansive soil. Study revealed that the heave can be reduced with increasing length and diameter of GAP. Johnson and Sandeep [9] conducted laboratory tests to study the effect of relative density of fill material and granular pile diameter on the pull capacity of the GAP. The pull-out capacity of the GAP observed to increase with relative density of the granular material and diameter of the GAP. Krishna and Murty [10] discovered that the GAPs exhibit promising pullout capacity even under fully wet condition compared to conventional concrete piles. Phanikumar [11] studied the influence of geogrid reinforcement on uplift capacity of GAP in expansive clay beds. The pullout capacity of the GAP increased with increasing number of geogrid layers, decreasing spacing between them, and with decreasing distance between anchor plate and bottom geogrid.

The uplift capacity can be accurately predicted only when reliable estimation of the in situ properties of the ground and of the granular pile material is possible. A method for determination of the same is presented here. Present study reports the field investigation of GAP at two sites. Estimation of uplift capacity from limit equilibrium approach is also discussed. The predicted capacities from limit equilibrium approach are in good agreement with measured uplift capacity of GAP in the field.

\subsection{METHODOLOGY}

Two sites are selected for conducting field investigations. They are designated as Site- 1 and Site- 2 . The detailed subsoil investigations in the field have been carried out at the selected sites. Then necessary laboratory investigations are carried out on disturbed/undisturbed samples collected from field for measurement of essential soil properties. Testing program included advancement of borehole supplemented with standard penetration tests (SPT) at regular intervals, dynamic cone penetration tests 
(DCPT) and static cone penetration tests (SCPT). Further, the undisturbed and disturbed soil samples were collected from appropriate locations for laboratory investigations. Basic classification tests were carried out on undisturbed samples.

\subsection{SITE-1}

The water table during the testing period was $6.2 \mathrm{~m}$ below ground. Study of bore log at site indicate the presence of poorly graded sand (SP) starting from the surface to $4 \mathrm{~m}$ depth. It is underlain by $1 \mathrm{~m}$ thick inorganic silt (ML). Again soil between $5 \mathrm{~m}$ to $8 \mathrm{~m}$ depth was found to be poorly graded sand (SP). Further extension of borehole beyond $8 \mathrm{~m}$ depth indicated the presence of this silty soil (ML). Observed SPT $N$ values at different depths are tabulated in Table 1 . Similarly static cone resistance values were recorded as $3600 \mathrm{kPa}$ and $3200 \mathrm{kPa}$ at $2 \mathrm{~m}$ and $3 \mathrm{~m}$ depth, respectively. But the values decreased to 2200 $\mathrm{kPa}$ and $1000 \mathrm{kPa}$ at $4 \mathrm{~m}$ and $6 \mathrm{~m}$ depth, respectively. Beyond this depth it was again observed increasing. The grain size analysis marked the presence of fine to medium sand between 82 to $97 \%$ with 10 to $12 \%$ of silt contents with almost no clay. However, a thin layer of $10 \%$ clay content was observed as exception.

Table 1 SPT value and angle of internal friction along depth at site-1

\begin{tabular}{ccc}
\hline $\begin{array}{c}\text { Depth } \\
(\mathrm{m})\end{array}$ & SPT $(N)$ & $\begin{array}{c}\text { Angle of } \\
\text { friction }\end{array}$ \\
\hline 0.75 & 6 & $28^{\circ}$ \\
3 & 6 & $28^{\circ}$ \\
5 & 11 & $29^{\circ}$ \\
6 & 12 & $29^{\circ}$ \\
7 & 14 & $30^{\circ}$ \\
8.5 & 9 & $29^{\circ}$ \\
\hline
\end{tabular}

\subsection{SITE-2}

As per the bore-log, the subsoil at the site reported an upper clay layer of intermediate plasticity (CI) starting from the ground surface to $3 \mathrm{~m}$ depth. It is followed by clay of low plasticity (CL) between $3 \mathrm{~m}$ to $6 \mathrm{~m}$ depth. Between $6 \mathrm{~m}$ to $10 \mathrm{~m}$ depth again clay of intermediate plasticity $(\mathrm{CI})$ was observed. Thus, the subsoil in general consists of soft cohesive-soil deposit ranging from CL to CI. Observed SPT $N$ values at different depths are tabulated in Table 2. The grain size analysis of samples collected from different depths was carried out using Digital Particle Size Analyzer. It indicated the presence of silt and clay. The percentages of silts varied from $95 \%$ to $52 \%$. Triaxial tests have been conducted on undisturbed samples of cohesive soils.

Table 2 Soil properties along depth at site-2

\begin{tabular}{cccccc}
\hline $\begin{array}{c}\text { Depth } \\
(\mathrm{m})\end{array}$ & SPT $(N)$ & $\begin{array}{c}\text { Liquid } \\
\text { limit }\end{array}$ & $\begin{array}{c}\text { Plastic } \\
\text { limit }\end{array}$ & $\begin{array}{c}\text { Cohesion } \\
\mathrm{kPa}\end{array}$ & $\begin{array}{c}\text { Angle of } \\
\text { friction }\end{array}$ \\
\hline 0.75 & 4 & & & & \\
1.5 & 7 & 43 & 22 & 50 & $15^{\circ}$ \\
3 & 10 & 43 & 24 & 50 & $10^{\circ}$ \\
4.5 & 9 & 29 & 17 & & $15^{\circ}$ \\
6 & 14 & 27 & 16 & 50 & \\
7.5 & 13 & 37 & 19 & $\mathrm{NP}$
\end{tabular}


Initially, borehole of desired depth in the ground is drilled using a manually operated spiral auger. Then, cement concrete mixture $(1: 2: 4)$ is poured at its bottom through a tremie pipe. Then a prefabricated anchor plate with anchor rod is lowered and positioned at the bottom. Another layer of $150 \mathrm{~mm}$ thick concrete is poured over anchor plate. Borehole is then left for seven days for initial setting of concrete. Then granular pile is installed with stone aggregate sand mixture in predetermined layers. Each layer was given uniform amount of compaction energy throughout the investigations.

After the test bed is ready, the other end of MS anchor rod is connected to the loading jack with the help of specially designed and fabricated attachment provided at its top to transfer the uplift force to the GAP system. The pullout force is then applied through the remote controlled hydraulic pump and jack placed at the loading/top girder of the MS frame. Pullout force is applied in increments. The exact load increment is measured through a load cell. The upward movement of GAP is measured with the help of two dial gauges. The uplift movements corresponding to each incremental uplift force were recorded till the soil fails in bulging.

In this study, the uplift capacity of single GAP and group of GAP system (both 2 GAP and 4 GAP system) is determined. In case of group piles, center to centre spacing of 3 times pile diameter is considered in the present study. The diameter of GAP is considered as $0.3 \mathrm{~m}$. But to examine the effect of diameter, two cases with $0.35 \mathrm{~m}$ diameter are also considered. To study the effect of Length to Diameter on uplift capacity of single GAP, four different $L / D$ ratios are considered in the field study. For the case of group GAP, $L / D$ ratio is taken as 20 .

\subsection{LIMIT EQUILIBRIUM APPROACH}

Bottom portion of GAP equal to critical height $H_{\mathrm{c}}$ is considered to bulge due to uniform lateral stress $\sigma_{\mathrm{r}}$ in subsoil due to gradual increase in uplift stress $q$ and consequently $\sigma_{\mathrm{r}}$ in pile body (Figure 2). Cylindrical zone around the bulged pile having a radius $R_{\mathrm{u}}$ will undergo a state of plastic equilibrium. Beyond this zone of plastic equilibrium of radius $R_{\mathrm{p}}$, soil is considered to be in elastic state. Ultimate uplift force applied at pile top is considered to be resisted by weight of GAP and force required to provide to restraint against bulging of GAP. Unit friction along the GAP shaft is not considered as there is no enough relative movement between GAP and surrounding soil. Ratio of radius of plastic zone and cylindrical cavity $\left(R_{\mathrm{p}} /\right.$ $R_{\mathrm{u}}$ ), reduced rigidity index $I_{\mathrm{rr}}$ and lateral limiting stress $\sigma_{\mathrm{rL}}$ are parameters controlling uplift capacity.

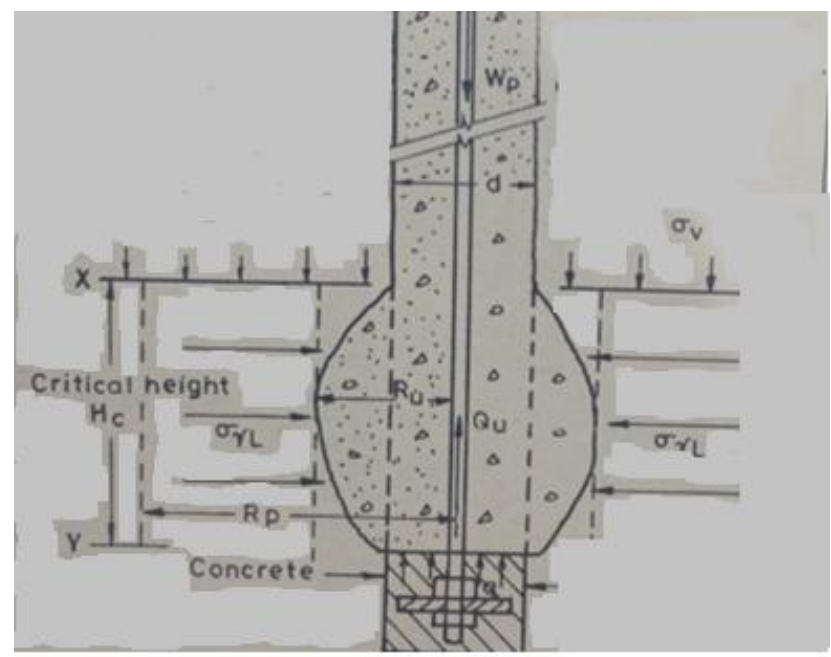

Figure 2 Bulging at bottom of GAP [12] 
Ultimate uplift capacity $Q_{\mathrm{u}}$ is calculated using following steps:

1. Effective normal stress $\sigma_{\mathrm{v}}$ at bulging

Assuming $H_{\mathrm{c}}$ equal to five times diameter of pile,

$$
\sigma_{v}=\gamma \times z=\gamma \times(L-5 D)
$$

2. Effective mean normal stress $\sigma_{\mathrm{m}}$

$$
\sigma_{m}=\left(\frac{1+2 K_{0}}{3}\right) \sigma_{v} \text { where } K_{0}=1-\sin (1.2 \phi)
$$

3. Elastic soil modulus is obtained from

$$
E_{s}=2 q_{c}\left(1+R_{D}^{2}\right)
$$

In which, $q_{\mathrm{c}}$ is static cone penetration resistance and $R_{\mathrm{D}}$ is relative density of soil.

Corrected Modulus

$$
E_{c o r}=E_{s}\left(\frac{\sigma_{v}}{100}\right)^{0.5}
$$

4. Rigidity Index $I_{\mathrm{r}}$

$$
I_{r}=\left(\frac{0.5 E_{c o r} /(1+\mu)}{c+\sigma_{m} \tan \phi}\right)
$$

Reduced Rigidity Index $I_{\mathrm{rr}}$

$$
I_{r r}=\left(\frac{I_{r}}{1+I_{r} \varepsilon_{v}}\right) \text { where } \varepsilon_{v}=\frac{\sigma_{m}}{K_{b u l k}}
$$

Dimensionless cavity expansion factors $F_{\mathrm{q}}$ and $F_{\mathrm{c}}$

$$
\begin{aligned}
& F_{q}=(1+\sin \phi)\left(I_{r r} \sec \phi\right)^{\sin \phi /(1+\sin \phi)} \\
& F_{c}=\left(F_{q}-1\right) \cot \phi \\
& F_{c}=1+\ln \left(I_{r r}\right) \quad \text { for } \quad \phi=0
\end{aligned}
$$

5. Lateral limiting stress $\sigma_{\mathrm{rL}}$ are

$$
\sigma_{r L}=F_{c} c_{u}+F_{q} \sigma_{m}
$$

6. Ultimate resistance in bulging $q_{\mathrm{ult}}$

$$
q_{u l t}=K_{p} \sigma_{r L}=\frac{1+\sin \phi_{p}}{1-\sin \phi_{p}} \times \sigma_{r L}
$$

7. Resistance in bulging $Q_{0}$

8. Weight of GAP

$$
Q_{0}=q_{u l t} A_{p}
$$

$$
W_{p}=\gamma_{p} A_{p} L
$$

9. Ultimate uplift capacity $Q_{\mathrm{u}}$

$$
Q_{u}=Q_{0}+W_{p}
$$

\subsection{RESULTS AND ANALYSIS}

The pullout capacities were obtained from the pullout force versus displacement curves by intersecting tangent methods. Values of pullout capacities are listed in Table 3 and 4. Values of pullout capacities are observed to be increasing with the increase in $L / D$ ratio. This increase is observed to be marginal beyond $L / D$ equal to 13.3. There is a particular length of pile beyond which further increase in length will not have significant effect on the pullout capacity. In the present study this length may be considered corresponding to $L / D$ ratio of about 13.3. For groups of GAP systems, the pullout capacities were found almost equal to the value of a single GAP system multiplied by the number of GAP systems. 
Table 3 Ultimate Uplift capacity at site-1

\begin{tabular}{|c|c|c|c|c|c|}
\hline \multirow[t]{2}{*}{ Type of GAP } & \multirow{2}{*}{\multicolumn{2}{|c|}{$L / D$}} & \multirow[t]{2}{*}{$S / D$} & \multicolumn{2}{|c|}{ Ultimate Uplift capacity (kN) } \\
\hline & & & & Field Test & Analytical \\
\hline Single & \multicolumn{2}{|c|}{6.66} & - & 45 & 27.4 \\
\hline Single & \multicolumn{2}{|c|}{10.0} & - & 70 & 54.1 \\
\hline Single & \multicolumn{2}{|c|}{13.3} & \multicolumn{2}{|r|}{75} & 67.7 \\
\hline Single & \multicolumn{2}{|c|}{20.0} & \multicolumn{2}{|r|}{80} & 78.8 \\
\hline 2 GAP & \multicolumn{2}{|c|}{20.0} & \multicolumn{2}{|r|}{170} & 157.6 \\
\hline 4 GAP & \multicolumn{2}{|c|}{20.0} & \multicolumn{2}{|r|}{310} & 315.2 \\
\hline \multicolumn{6}{|c|}{$\begin{array}{l}\text { GAP- Granular Anchor Pile, } 2 \text { GAP- Group of } 2 \text { GAP, } 4 \text { GAP- Group of } 4 \text { GAP, } \\
\qquad / D \text { - c/c pile spacing to diameter ratio in group pile }\end{array}$} \\
\hline \multicolumn{6}{|c|}{ Table 4 Ultimate Uplift capacity at site-2 } \\
\hline \multirow[t]{2}{*}{ Type of GAP } & $L / D$ & \multirow[t]{2}{*}{$D(\mathrm{~m})$} & $S / D$ & \multicolumn{2}{|c|}{ Ultimate Uplift capacity $(\mathrm{kN})$} \\
\hline & & & & Field Test & Analytical \\
\hline Single & 6.66 & 0.3 & - & 35 & 44.0 \\
\hline Single & 13.3 & 0.3 & - & 45 & 48.9 \\
\hline Single & 20.0 & 0.3 & - & 47 & 54.4 \\
\hline 2 GAP & 13.3 & 0.3 & 3 & 80 & 97.8 \\
\hline 2 GAP & 20.0 & 0.3 & 3 & 90 & 108.8 \\
\hline 2 GAP & 20.0 & 0.35 & 3 & 200 & 154.8 \\
\hline 3 GAP & 13.3 & 0.3 & 3 & 120 & 146.7 \\
\hline 3 GAP & 20.0 & 0.3 & 3 & 140 & 163.2 \\
\hline 3 GAP & 20.0 & 0.35 & 3 & 220 & 222.2 \\
\hline 6 GAP & 13.3 & 0.3 & 3 & 260 & 293.4 \\
\hline 6 GAP & 20 & 0.3 & 3 & 300 & 326.4 \\
\hline
\end{tabular}

Analytical estimation of pull out capacity is also given in the same tables for comparison. The pull out capacity of group of GAP is estimated by multiplying number of piles with capacity of single GAP. It forces group efficiency equal to one. Assuming densification of soil taking place in the installation and pile spacing greater than or equal to 3 times diameter, this assumption is justifiable. The comparison of field and analytical result indicates average error of $15 \%$ with field results. Difference is more for lower values of $L / D$ ratio. With increase in of $L / D$ ratio good agreement is observed between field and analytical approaches.

Various parameters that are observed to influence the ultimate pullout capacity of the GAP system in the present study were length, diameter, spacing, number of GAP and the soil characteristics.

\subsection{PERFORMANCE STUDY}

Granular anchor pile (GAP) are mainly designed focusing its ability to resist uplift forces. In the present study, the performance of GAP and pile of same length and diameter are compared from economic considerations and their ultimate capacities. In the economic comparison, it is assumed that cost of installation of GAP and concrete pile is nearly same. Hence, only material costs are compared. Material costs are evaluated for four $L / D$ considered in the study. Their material cost is reported in Table 5 along with percentage difference. It can be observed that material cost is nearly increased by $100 \%$ for concrete piles. Difference is increasing with $L / D$ ratio. Similarly, uplift capacity of concrete pile in same ground conditions are evaluated for four $L / D$ considered in the study. The uplift capacity of GAP and pile are compared in Table 5. For smaller $L / D$ ratio capacity of pile is $77 \%$ less as compared to GAP. However, with increase in length, difference in capacity is reducing. For $L / D$ ratio of 20 , capacities are almost equal. This fact again underlines the importance of optimum $L / D$ ratio of GAP. 
Table 5 Ultimate Uplift capacity at site-1for 300mm diameter GAP

\begin{tabular}{|c|c|c|c|c|c|c|c|}
\hline \multirow[t]{2}{*}{ No. } & \multirow[t]{2}{*}{$\mathrm{L} / \mathrm{d}$} & \multirow{2}{*}{$\begin{array}{c}\text { Material cost } \\
\text { of GAP } \\
\text { (INR) }\end{array}$} & \multirow{2}{*}{$\begin{array}{l}\text { Material cost } \\
\text { of concrete } \\
\text { pile (INR) }\end{array}$} & \multirow{2}{*}{$\begin{array}{c}\% \\
\text { difference }\end{array}$} & \multicolumn{2}{|c|}{$\begin{array}{l}\text { Ultimate Uplift capacity of } \\
\qquad \mathrm{GAP}(\mathrm{kN})\end{array}$} & \multirow{2}{*}{$\begin{array}{l}\text { Concrete Pile } \\
\text { Strength }(\mathrm{kN})\end{array}$} \\
\hline & & & & & Field Test & Analytical & \\
\hline 1 & 6.66 & 836.80 & 1653.25 & 97.57 & 45 & 27.4 & 9.92 \\
\hline 2 & 10.0 & 1096.64 & 2248.58 & 105.04 & 70 & 54.1 & 20.19 \\
\hline 3 & 13.3 & 1356.48 & 2843.91 & 109.65 & 75 & 67.7 & 34.39 \\
\hline 4 & 20.0 & 1876.16 & 4034.57 & 115.04 & 80 & 78.8 & 74.02 \\
\hline
\end{tabular}

\subsection{CONCLUSIONS}

The analysis of field test data indicate that the GAP system is an effective foundation system for structure subjected to uplift loads. Various parameters that are observed to influence the ultimate pullout capacity of the GAP system in the present study were length, diameter, spacing, number of GAP and the soil characteristics. Based on the study following conclusions are made:

1.Pullout capacities are observed to be increasing with the increase in $L / D$ ratio up to an optimum value for $L / D$ ratio.

2.For groups of GAP systems, the pullout capacities were found almost equal to the value of a single GAP system multiplied by the number of GAP systems.

3. The comparison of field and analytical result indicates average error of $15 \%$ with field results. Difference is more for lower values of $L / D$ ratio. With increase in of $L / D$ ratio good agreement is observed between field and analytical approaches.

4. From economic considerations, the material cost of GAP is nearly half of the concrete pile of same dimension. Hence it can be considered as an alternative option to pile foundation where site is not prone to earthquake hazard.

5. Comparison of uplift capacities indicated that GAP is more effective than pile at smaller $L / D$ ratio.

\section{REFERENCES}

[1] Kumar, P. (2002). Granular Anchor Pile System under Axial Pullout Loads, Ph.D, Thesis, I.I.T, Roorkee.

[2] Phanikumar, B.R. (1997), A Study of Swelling Characteristics of Granular Pile Anchor Foundation System in Expansive Soils". Ph.D. Thesis, JNTU, Kakinada

[3] Ranjan, G. and Kumar, P. (2000), Behaviour of Granular Piles under Compressive and Tensile Loads, Geotechnical Engineering, J. of SEAGS, 31(3) : 209-214.

[4] Madhav, M.R and Vidyaranya, B. (2005), Analysis and Displacements of Granular Anchor Piles, International Conference on Soil-Structure Interaction, St. Petersburg.

[5] Kranthikumar, A, Sawant, V. A., Pradeep Kumar and Shukla, S K, (2017), Numerical and Experimental Investigations of Granular Anchor Piles in Loose Sandy Soil Subjected to Uplift Loading, International Journal of Geomechanics, ASCE, 17(2): 04016059, 1-10

[6] Kumar, P. and Ranjan, G. 1999. Granular Pile System for Uplifting Loads A Case Study. Int. Conf. on Offshore and Near shore Geotechnical Engineering, GEOSHORE, Mumbai, pp.427-432.

[7] Phanikumar, B.R., Sharma, R.S., Srirama Rao, A. and Madhav, M.R. 2004. Granular Pile Anchor Foundation System for Improving the Engineering Behaviour of Expansive Clay Beds. Geotech. Testing J., ASTM, 27(3):1-9.

[8] Ibrahim, S. F., Aljorany, A. N., \& Aladly, A. I. (2014). Heave behavior of granular pile anchor-foundation (GPAfoundation) system in expansive soil. J. Civil Eng. Urban, 4(3), 213-222.

[9] Johnson, N., \& Sandeep, M. N. (2016). Ground Improvement Using Granular Pile Anchor Foundation. Procedia Technology, 24, 263-270.

[10] Krishna, P. H., \& Murty, V. R. (2016). Anchor Piled Footings-An Alternative Foundation Technique in Expansive Soils. International Journal of Advanced Research in Engineering, 2(2), 17-21.

[11] Phanikumar, B. R. (2016). Influence of Geogrid Reinforcement on Pullout Response of Granular Pile-Anchors (GPAs) in Expansive Soils. Indian Geotechnical Journal, 46(4), 437-444.

[12] Rao, B. G. (1982), Behaviour of Skirted Granular Piles, Ph.D, Thesis, University of Roorkee, Roorkee. 